\title{
Misiune prin Euharistie în parohia de azi. Exemple pastorale din opera Sfântului Ioan Gură de Aur
}

\section{Silviu Marcel COSTIN}

Abstract: Given the galloping technological progress, the parish is faced with new pastoral situations. The management of these situations depends heavily on whether or not the future based on the values of the Orthodox faith of these communities. Using less the "liturgical treasure" that it has orthodoxy results in visible today, migrating a large number of protestant denominations faithful to (data confirmed last census). One of the "pieces" of this treasure, little used in some Orthodox parishes in Romania is the Eucharist. It is well known that in many parish communities, especially those in urban areas, confession and communion is linked to the four posts of the year or just for Lent. In the rest of the time, most of the community is absent from liturgical program. In many parishes, especially in urban areas, the exact number is not known to the faithful from the parish but the first step of data provided by the civil authorities. Sharing the Body and Blood of Christ continues, preceded by confession, would have the effect of increasing the number of believers who consciously and fully participate in the Mass and considerably increasing the efficiency of the mission carried out in that parish. An example in this case is exceptional pastoral held by St. John Chrysostom after more than 17 centuries. As it can be seen in 
many homilies and letters, St. John Chrysostom makes explicit reference to the importance of the participation of the faithful in worship of the Church and the reception of the Eucharist. The same Holy Father points out that believers near Holy Eucharist is a duty of the priest: "Sanctify yourself, deifies with God's body as often. Sanctifies and deifies as well as your faithful. All this power is in your hand. God gave it to you. "

Keywords: church, mission, parish priest, the Eucharist, the faithful.

\section{Misiune prin Euharistie}

In condițiile unui progres tehnologic galopant, parohia este pusă în faţa unor situații pastorale noi. De gestionarea acestor situaţii depinde în foarte mare măsură existenţa sau inexistența unui viitor bazat pe valorile credinţei ortodoxe a acestor comunităţi. Participarea tuturor credincioşilor la viaţa liturgică a parohiei trebuie să rămână regula de aur a pastorației ${ }^{1}$. Nici o tehnică pastorală nu poate să înlocuiască forța de atracție și de coeziune a cuvântului predicat, a Sfintei Liturghii, a Sfintelor Taine și a cultului Bisericii în general². Neutilizarea întregului ,tezaur liturgic” pe care îl are ortodoxia are drept efect vizibil astăzi, migrarea unui număr important de credincioși către cultele neoprotestante (date confirmate de ultimul recensământ) ${ }^{3}$.

Una dintre ,piesele” acestui tezaur, puțin utilizată în unele parohii ortodoxe din România este Euharistia. Este bine-cunoscut faptul că în numeroase comunități parohiale, cu precădere cele din mediul urban, spovedania și împărtășania este legată de cele patru

\footnotetext{
${ }^{1}$ Valer Bel, Misiune, parohie, pastorație, Cluj-Napoca, Editura Renașterea, 2006, p. 61.

${ }^{2}$ Ibidem.

${ }^{3}$ http://www.insse.ro/cms/files/publicatii/pliante\%20statistice/08-Recensamintele\%20despre\%20religie_n.pdf, pagină accesată în data de 30.06.2015, ora $16: 12$
} 
posturi de peste an sau doar de Postul Mare. În restul timpului, cea mai mare parte a comunității absentează de la programul liturgic ${ }^{4}$. Prezentând câteva date statistice realizate în Grecia, Mitropolitul Emilianos Timiadis arată că doar $20 \%$ dintre persoanele care se declară a fi creștine (ortodoxe) participă duminica la Sfânta Liturghie ${ }^{5}$. Se întreabă mitropolitul Timiadis și este pertinent să ne întrebăm și noi: care este cauza absenți masive a credincioșilor (declarați) de la cultul Bisericii? ${ }^{6}$. Recent au fost publicate câteva sondaje de opinie legate de religiozitatea românilor care vor face obiectul analizei într-una dintre secțiunile acestei lucrări. Chiar dacă cifrele statisticie se referă la Grecia, se poate spune că nici în România situația nu este foarte mult diferită din acest punct de vedere. În asemenea împrejurare, preotul cunoaște doar o parte dintre enoriașii încredințați spre păstorire. În foarte multe parohii, mai ales din mediul urban, numărul exact al credincioșilor nu este cunoscut în urma unui demers ințiat de parohie ci din datele oferite de autorităţile civile. Mitropolitul Emilianos Timiadis încadrează acest segment de credincioși inactivi în categoria celor care trebuie să fie incluși în proiectele celui de-al doilea front pastoral, adică cel „extra”’ Ierarhul amintit precizează că atragerea sufletelor încă neatinse de Evanghelie trebuie să constituie o preocupare principală a fiecărui preot de parohie ${ }^{8}$. Și alți teologi afirmă că recuperarea dimensiunii unității trăite în Euharistie este esențială pentru omul din zilele noastre măcinat de tendințe centrifugale care-1 dezbină atât sufletește cât și trupește de Biserică ${ }^{9}$. Așadar, Euharistia reprezintă pentru conștiința teologică modernă, Taina Bisericii prin

${ }^{4}$ Emilianos Timiadis, Preot, parohie, înoire, București, Editura Sophia, 2001, pp. 93-94, 123, 187.

${ }^{5}$ Ibidem, p. 123.

${ }^{6}$ Ibidem.

${ }^{7}$ Ibidem, p. 121.

${ }^{8}$ Ibidem, p. 123.

${ }^{9}$ Gheorghe Ispas, Euharistia-Taina unităţii Bisericii, București, Editura Basilica, 2008, p. 128. 
excelență, Taină în care Biserica se recunoaște și se perpetuează, fiind punct de plecare al mărturiei și al expansiunii misionare și apostolice a întregii Biserici ${ }^{10}$. Părintele Boris Bobrinskoi reamintește faptul că trebuie să vorbim despre Euharistie ca o manifestare plenară şi veritabilă a Bisericii în taina sa mântuitoare și dătătoare de viață ${ }^{11}$.

Împărtășirea continuă cu Trupul și Sângele Mântuitorului, precedată de spovedanie, ar avea drept efect creșterea numărului credincioșilor care participă în mod conștient și deplin la Sfânta Liturghie și o creștere considerabilă a eficienței misiunii desfășurată de preot în respectiva parohie. Credincioșii ar conştientiza mult mai bine că biserica nu este o simplă „casă de adunare” unde sunt invitații pentru a cânta și a fi „evanghelizați” ci un loc al prezenței lui Hristos $^{12}$ de care ne putem împărtăşi în mod real. Această împărtășire este validă numai după ce darurile au fost sfințite de arhiereu sau preot $^{13}$. Înafara clericilor menționați, nimeni nu poate pretinde că poate săvârşi această Sfântă Taină, dar și alte Sfinte Taine (înafara Botezului în caz de necesitate, Taina Hirotoniei în treapta diaconiei și preoției poate fi săvârșită doar de arhiereu, iar în cazul hirotoniei unui nou episcop este obligatorie conlucrarea a cel puțin trei arhierei). Încă din primul secol de existență a Bisericii, nu orice fel de adunare a unor oameni era numită Biserică, ci numai adunarea euharistică a fost numită ekklesia „Bisericii”'14. Mitropolitul Ioannis Zizioulas argumentează această afirmație prin exemple concrete, extrase din unele epistole ale Sfântului Apostol Pavel în care marele

\footnotetext{
${ }^{10}$ Boris Bobrinskoi, Taina Bisericii, Alba Iulia, Editura Reîntregirea, 2004, p. 44.

${ }^{11}$ Ibidem, p. 218.

${ }^{12}$ Valer Bel, op. cit., p. 65.

${ }^{13}$ Ene Braniște, Liturghierul explicat, București, Editura Institului Biblic și de Misiune al Bisericii Ortodoxe Române, 1998, pp. 259-268.

${ }^{14}$ Ioannis Zizioulas, Euharistie, Episcop, Biserică. Unitatea Bisericii $\hat{\imath}$ dumnezeiasca Euharistie și episcop în primele trei secole creștine, București, Editura Basilica, 2009, p. 49.
} 
propovăduitor folosește expresiile de „Biserica lui Dumnezeu din Corint” (II Cor. 1, 1), „Biserica lui Dumnezeu” (I Cor. 11, 22) ${ }^{15}$. În lipsa împărtășirii continue, unii dintre credincioși nu au o apartenență fermă la adevărata Biserică, considerând că nu este un lucru greșit să participe și la manifestările religioase ale altor culte, invocând faptul că „şi acolo este Dumnezeu". Toate cultele neoprotestante pun accentul pe implicarea tuturor membrilor în cântarea comună. În cadrul acestor manifestări are loc intonarea unor „cântări” pioase, multe dintre ele cu caracter ,lacrimogen”, mesajul acestora sensibilizându-l pe participant „să se întoarcă sau să rămână la Domnul”. Acest lucru îi motivează pe unii dintre creștini să participe în mod repetat la „adunările” lor, fiind astfel foarte ușor de convins să se îndepărteze de Biserică. De foarte multe ori îți este dat să auzi că simpla apartenență (activă) la aceste culte îți asigură mântuirea, lucru absurd și care nu poate fi demonstrat. Trebuie precizat că prezența acestor culte, creștine și necreștine, în numeroase locuri publice (stadioane, case de cultură) și manifestarea zgomotoasă (cântatul cu instrumente muzicale, baterea tobelor etc.) are rolul de atrage atenția asupra activității lor. Încheierea acestor manifestări se face de foarte multe ori prin împărțirea de cărți, reviste, pliante, participanților, materiale care conțin și o invitație la o „evanghelizare” gratuită, activitate care se poate desfăşura la „casa de adunare" sau chiar la domiciliul celui interesat. În acest fel, unii dintre credincioșii noştri inactivi cad pradă prozelitismului, devenind, treptat, membrii ai acestor culte neoprotestante. Este interesant faptul că toate aceste culte pretind că sunt „Biserici” și că predică „Evanghelia”, deși locuitorii de pe actualul teritoriu a României au primit cuvântul Evangheliei acum aproape două mii de ani prin gura Sfântului Apostol Andrei, perioadă în care aceste culte nu existau. Interpretând în mod propriu versetele 19 și 20 din capitolul 28 al Evanghelia de la Matei, neoprotestanții se consideră urmași ai apostolilor și în consecință își atribuie rol de propovăduitori, chiar

${ }^{15}$ Ibidem, pp. 49-52. 
dacă teritoriul în care fac prozelitism este deja unul încreștinat de mii de ani.

În condițiile actuale, pastorația preotului trebuie să fie una mult mai intensă, scopul fiind formarea unui nucleu parohial bine-închegat. Elementul care dă viaţă acestui nucleu este Euharistia. Chiar dacă primirea Trupului și a Sângelui Domnului este considerată a fi un act individual, totuși prin împărtășirea tuturor credincioșilor din același Potir, Euharistia devine un act comunitar ${ }^{16}$. In acest fel trecem de la teorie la faptă, efectul fiind creșterea vizibilă a practicii sacramentale în rândul credincioșilor din parohie și implicit din întreaga Biserică ${ }^{17}$. Fără a avea statistici putem observa cu ușurință (televiziune, internet etc.) că în majoritatea bisericilor din Patriarhia Română, numărul credincioșilor care se împărtășesc în mod regulat la Sfânta Liturghie este unul destul de mic. În multe situații ne este dat să vedem că din câteva zeci, sute sau mii de credincioşi care participă în mod regulat la Sfânta Liturghie, la bisericile de care aparțin administrativ sau la hramurile unor mănăstiri și biserici, numai o mică parte dintre adulți se și împărtăşesc, iar în unele situaţii nu se împărtăşesc nici măcar copiii. Motivele invocate sunt multiple, de la nevrednicie ${ }^{18}$ la neștiință. Trebuie precizat ferm că Sfânta Liturghie nu își atinge scopul pentru care a fost instituită de Mântuitorul Hristos dacă nimeni (înafară de preotul săvârșitor) nu s-a împărtășit la respectiva slujbă. Sfântul Nicolae Cabasila arată că săvârșirea Sfântei Liturghii are ca obiect prefacerea darurilor de pâine și vin în Trupul și Sângele Mântuitorului Hristos, iar scopul acestei prefaceri este sfințirea credincioșilor prin

\footnotetext{
${ }^{16}$ Valeriu Anania, Cartea deschisă a Impărăției. O însoțire liturgică pentru preoți și mireni. De la Betleemul Nașterii, la Ierusalimul Învierii, Iași, Editura Polirom, 2011, p. 214.

${ }^{17}$ Impărtășirea continuă cu Sfintele Taine. Dosarul unei controverse. Mărturiile Tradiției, studiu introductiv și traducere de diac. Ioan I. Ică jr., Sibiu, Editura Deisis, 2006, pp. 6-7.

${ }^{18}$ Alexander Schmeman, Euharistia. Taina împărăției, traducere din limba rusă de pr. Boris Răduleanu, București, Editura Sophia, 2012, p. 275.
} 
împărtăşirea din ele ${ }^{19}$. Un lucru pozitiv este sesizarea problemei referitoare la împărtășirea rară a credincioșilor de către ierarhie. În acest sens Sfântul Sinod a declarat anul 2014 drept „anul omagial euharistic". Observând, cu ocazia vizitelor pastorale sau a slujbelor de hram sau de târnosire a altarelor, că în unele parohii numărul credincioșilor care se împărtășesc este mic sau foarte mic, unii ierarhi au îndemnat credincioșii, în predici, să se spovedească mai des și să participe la împărtăşire în mod regulat ${ }^{20}$. Acest îndemn este prezent şi în articolele de liturgică din cotidianul „Lumina” al Patriarhiei Române, ziar care ajunge în toate eparhiile și parohiile din țară $\breve{a}^{21}$.

\section{Exemple din pastorația Sfântului Ioan Gură de Aur}

Chiar dacă a trăit cu 17 secole în urmă, Sfântul Ioan Gură de Aur rămâne un model de păstor de suflete pentru preoții și credincioșii din zilele noastre. Desfăşurând o pastorație excepțională, marele părinte antiohian pune accentul pe rolul preotului în formarea comunității ${ }^{22}$. Absența unora dintre credincioșii încredințați lui spre

${ }^{19}$ Nicolae Cabasila, Tâlcuirea dumnezeieștii Liturghii, București, Editura Arhiepiscopiei Bucureștilor, 1989, p. 2.

${ }^{20}$ Andrei Andreicuț, Ospățul credinței, Editura Renașterea, 2011, p.

$21 \mathrm{http} / / /$ ziarullumina.ro/cum-ajungem-la-impartasirea-continua-cu-sfinteletaine--93840.html; $\quad$ http://ziarullumina.ro/bun-si-folositor-lucru-este-a-necumineca-si-impartasi-88603.html; $\quad$ http://ziarullumina.ro/de-ce-m-as-maispovedi-si-impartasi-pana-la-urmatorul-post--94482.html;

http://ziarullumina.ro/In-ce-conditii-ma-pot-impartasi-in-saptamanaluminata--91161.html;

http://ziarullumina.ro/sa-mi-fie-Impartasania-aceasta-spre-bucurie-sanatate-siveselie-94950.html;

http://ziarullumina.ro/bucuria-Impartasirii-si-puterea-credintei-8760.html, pagini accesate în data de 02.07.2015.

${ }^{22}$ Sfântul Ioan Gură de Aur, Tratatul despre preoție, în vol. „Despre preoție”, trad. introducere şi note de Pr. Dumitru Fecioru, București, Editura Sophia, 
păstorire de la Sfânta Liturghie, plecarea de la slujbă înainte ca ea să se fi încheiat, absența de la slujba vecerniei și de la programul catehetic, au fost probleme sesizate foarte repede de arhiepiscopul Ioan al Constantinopolului și aduse la cunoștința credincioșilor:

„după atâtea cuvinte îndelungate și după atâtea învățături unii, lăsându-ne pe noi, s-au dus să privească la caii ce se intrec în hipodrom și așa au înebunit, încât toată cetatea au umplut-o de strigare și de răcnete fără rânduială, pricinuind mult râs, dar mai vârtos plâns. Eu stând în casă și auzind izbucnind strigarea aceea pătimeam mai cumplit decât cei ce se înviforează. Ce vom grăi sau ce vom răspunde spre a ne îndreptăți, dacă vreun străin venind va vedea unele ca acestea?"23, [...] „Mielul lui Dumnezeu este injunghiat pentru tine, preotul se nevoiește pentru tine, foc duhovnicesc izvorăște din preacurata masă, heruvimii stau împrejur, serafimii, care cu șase aripi iși acopăr fețele, zboară pe deasupra, toate puterile cele netrupești împreună cu preotul se roagă pentru tine, focul cel duhovnicesc se pogoară, sânge curge din preacurata coastă în potir spre curățirea ta, și tu nu te înfricoșezi că ești găsit mincinos în acest înfricoșător ceas? Ai o sută șaizeci și opt de ore pe săptămână și din aceste Dumnezeu și-a oprit pentru El numai o singură oră; și cheltuiești această oră în treburi lumești, în glume, în discuții. Cu ce îndrăznire te mai apropii de sfintele taine? [...] Așadar, fraților, să nu plecăm din Biserică în timpul Sfintei Liturghii; și iarăși, nici când suntem în biserică, să nu stăm de vorbă"24, [...],,mică ne este adunarea de astăzi; mai puțini credincioși au venit astăzi la Biserică. Pentru ce? Care e pricina? Poate că unii s-au rușinat să mai vină la masa aceasta duhovnicească după ce au stat acasă la masă [...] Chiar de te prinde seara, nici ea nu-i o piedică în calea învățăturii celei duhovnicești" 25 .

Pe lângă aceste îndemnuri, în numeroase dintre scrierile acestui Sfânt Părinte nu lipsesc referirile în legătură cu participarea credincioșilor la Sfânta Împărtășanie. Conștientizarea credincioșilor

2004, pp. 172-173.

${ }^{23}$ Sfântul Ioan Gură de Aur, Din ospățul Stăpânului, introducere, traducere, note și comentarii de Irineu Slătineanul, București, Editura Adonai, 1995, pp. 107108.

${ }^{24}$ Ibidem, pp. 186-187.

${ }^{25}$ Idem, Omilii la Facere, vol. I, București, Editura Institului Biblic şi de Misiune al Bisericii Ortodoxe Române, 2003, p. 100. 
asupra însemnătății acestei taine este considerată o datorie a preotului: „sfințește-te, îndumnezeiește-te cu trupul lui Dumnezeu cât mai des. Sfințește și îndumnezeiește la fel și pe credincioșii tăi. Toată puterea aceasta este în mâna ta. Ți-a dat-o Dumnezeu" ${ }^{26}$. Dacă în zilele noastre participarea la Taina Sfintei Euharistii constuie o problemă în multe parohii, în perioada păstoririi Sfântului Ioan Gură de Aur credincioșii luau parte la această Taină în număr mult mai mare. Pentru a preîntâmpina instalarea formalismului în rândul credincioșilor săi, Sfântul Ioan Gură de Aur le reamintea care sunt responsabilităţile pe care un credincios trebuie să le aibă înainte și după primirea Sfintei Împărtășanii:

,în vechime, mulți se apropiau de Sfintele Taine fără nici o pregătire, la întâmplare, și mai ales în acest timp pe care Hristos ni l-a dat (n.a timpul postului). Părinții, dându-și seama de vătămarea pe care o are cineva când se apropie nepregătit de Sfintele Taine, s-au adunat și au rânduit patruzeci de zile de post, de rugăciuni, de ascultare a sfintei slujbe și a predicii, de venire deasă la biserică, pentru ca în aceste zile toți să ne curățim cu toată grija prin rugăciuni, prin milostenii, prin post, prin slujbe de toată noaptea, prin lacrimi, prin spovedanie și prin toate celelalte, și astfel, după puterea noastră, să ne apropiem cu conștiința curată de Sfintele Taine"27.

Tactul pastoral a Sfântului Ioan i-a apropiat de Biserică chiar şi pe cei mai sceptici dintre locuitorii cetăți. Într-una dintre omiliile ținute cu câteva zile de Sărbătoarea Nașterii Domnului, ierarhul i-a îndemnat pe toți cei care au stat departe de Biserică să se întoarcă cu pocăință, având nădejdea că vor fi primiți de Dumnezeu: „răgazul acesta de cinci zile până la Nașterea Domnului este îndestulător ca să lepezi mulțimea păcatelor, dacă te înfrânezi, dacă te rogi, dacă priveghezi. Nu te uita că timpul e scurt! Uită-te la aceea că Stăpânul este iubitor de oameni"28. Față de creștinii care fără motiv întemeiat nu se împărtășeau în mod regulat, Sfântul Ioan Gură de Aur nu a manifestat o atitudine

\footnotetext{
${ }^{26}$ Idem, Tratatul despre preoție..., p. 19.

${ }^{27}$ Sfântul Ioan Gură de Aur, Cuvânt împotriva anomeilor. Către iudei, București, Editura Institului Biblic și de Misiune al Bisericii Ortodoxe Române, 2007, p. 281. ${ }^{28}$ Ibidem, p. 101.
} 
pozitivă, averizându-i că vor pierde mântuirea dacă nu se vor îndrepta: „căci cum s-ar apropia cineva cum s-ar întâmpla este primejdios, tot așa și a nu se împărtăși de cina cea de taină este primejdios, este foame, este moarte veșnică. Această masă este puterea noastră, este legătura cugetului, pricină de încurajare, nădejdea, mântuirea, lumina și viața noastră ${ }^{29}$. Din vasta operă a Sfântului Ioan Gură de Aur mai putem desprinde un mesaj foarte important pentru omul contemporan, trăitor într-o lume în care se încearcă o relativizare a valorilor: ,întoarce-te la Biserică, maica ta, pentru că ai fost despărțit atâta vreme de ea! Nimeni nu spune: Îmi este rușine să mă împac acum, pentru că am dus-o atâta vreme în dușmănie! Nu e rușine să te schimbi în mai bine, ci să stărui intr-o ambiție deșartă" ${ }^{30}$.

\section{Românii, credința și sondajele}

Așa cum am menționat în prima parte a comunicării şi în România s-au realizat o serie de sondaje care au dorit să arate cum se raportează românii la credinţă. Institutele de sondare a opiniei publice s-au arătat, în mod surprinzător, interesate și de acest subiect. Perioada aleasă pentru a efectua acest tip de cercetare a fost cea de-a doua parte a Postului Mare. Institutul Român Pentru Evaluare și Strategie din ClujNapoca a publicat pentru prima dată rezultatele unui astfel de sondaj în 2011. Datele arată că în respectivul an doar 10\% dintre respondenţi ținuse integral post alimentar până în momentul efectuării sondajului, $47 \%$ doar în zilele de miercuri și vineri, iar 17\% au declarat că vor ține post doar în Vinerea Mare. ${ }^{31}$ Un alt lucru alarmant este faptul că $24 \%$ dintre respondenți au declarat că nu au obiceiul de a ține post, iar

${ }^{29}$ Idem, Tâlcuiri la epistola întâi către Corinteni, Ediție revizuită de Constantin Făgețan, București, Editura Sophia, 2005, p. 256.

${ }^{30}$ Idem, Cuvânt împotriva anomeilor..., p. 285.

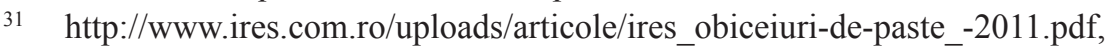
pagină accesată în data de 02. 07. 2015. 
$37 \%$ că nu se spovedesc. Până în momentul efectuării sondajului doar $20 \%$ dintre respondenți au declarat că s-au spovedit, iar $41 \%$ că vor face acest lucru în perioada următoare. ${ }^{32}$ În 2015, deși, $87 \%$ dintre respondenți au declarat că se consideră o persoană religioasă, dar doar $74 \%$ au declarat că merg la Biserică. ${ }^{33}$ Dintre credincioșii care au declarat că merg la Biserică, $15 \%$ au declarat că merg de mai multe ori pe săptămână, $44 \%$ merg de câteva ori pe lună, $18 \%$ la sărbătorile importante, $14 \%$ de câteva ori pe an, iar $6 \%$ mai rar, cifrele fiind asemănătoare cu cele înregistrate în ultimii cinci ani ${ }^{34}$. Referitor la primirea Tainei Spovedaniei, 25\% dintre respondenți au declarat că s-au spovedit, $33 \%$ că se vor spovedi, iar $39 \%$ că nu se vor spovedi deorece nu au acest obicei ${ }^{35}$. Și aceste cifre sunt asemănătoare cu cele înregistrate în ultimii patru ani. Un aspect mult mai grav este cel legat de percepția celor care s-au declarat credincioși în legătură cu Taina Împărtășaniei. Datele sondajului arată că $25 \%$ dintre respondenți au declarat că s-au împărtășit, $35 \%$ că urmează să se împărtășească, iar $38 \%$ că nu practică acest lucru ${ }^{36}$. În schimb, $80 \%$ dintre respondenți au declarat că vor merge la slujba de Înviere. ${ }^{37} \mathrm{Ne}$ putem întreba: Cum se poate declara cineva credincios dacă nu se spovedește și nu se împărtășește?. La o analiză sumară a datelor putem constata că găsirea soluțiilor pastorale potrivite pentru înlăturarea acestui indiferentism liturgic și euharistic trebuie să constituie o prioritate pentru toții preoții de parohie.

\footnotetext{
${ }^{32}$ Ibidem .

33 http://www.ires.com.ro/uploads/articole/ires_sarbatorile-pascale-la-romani 2015.pdf, pagină accesată în data de 02. 07. 2015.

${ }^{34}$ Ibidem.

${ }^{35}$ Ibidem .

${ }^{36}$ Ibidem.

${ }^{37}$ Ibidem.
} 


\section{Concluzii și recomandări}

Declararea anului 2015 drept „Anul omagial al misiunii parohiei și mănăstirii azi” este un bun prilej pentru intensificarea misiunii în toate parohiile Patriarhiei Române cu scopul de a consolida nucleele parohiale și a le ,imuniza” în fața prozelitismului cultelor neoprotestante. Un mijloc pastoral care poate fi folosit în acest important demers este Sfânta Euharistie (nu fără discernământ).

Este necesară implementarea unui program catehetic unitar, la nivelul întregii Patriarhii, cu o programă aprobată de Sfântul Sinod al Bisericii Ortodoxe Române, în conformitate cu cerințele și situațiile cu care se confruntă parohiile din vremea actuală.

Obligativitatea pentru parohiile mari și înstărite (de peste 500 de credincioși) de a avea o bibliotecă funcțională din care să nu lipsească cele mai reprezentative lucrări de liturgică în care credincioşii interesați să poată găsi explicarea cultului Bisericii.

\section{Bibliografie}

1. Anania Valeriu, Cartea deschisă a Împărăției. O însoțire liturgică pentru preoți și mireni. De la Betleemul Nașterii, la Ierusalimul Invierii, Iași, Editura Polirom, 2011.

2. Andreicuț Andrei, Ospățul credinței, Editura Renașterea, 2011.

3. Bel Valer, Misiune, parohie, pastorație, Cluj-Napoca, Editura Renașterea, 2006.

4. Bobrinskoi Boris, Taina Bisericii, Alba Iulia, Editura Reîntregirea, 2004.

5. Branişte Ene, Liturghierul explicat, București, Editura Institului Biblic și de Misiune al Bisericii Ortodoxe Române, 1998.

6. Cabasila Nicolae, Tâlcuirea dumnezeieștii Liturghii, București, Editura Arhiepiscopiei Bucureștilor, 1989.

7. Ispas Gheorghe, Euharistia-Taina unității Bisericii, București, Editura Basilica, 2008.

8. Împărtășirea continuă cu Sfintele Taine. Dosarul unei 
controverse. Mărturiile Tradiției, studiu introductiv și traducere de diac. Ioan I. Ică jr., Sibiu, Editura Deisis, 2006.

9. Schmeman Alexander, Euharistia. Taina împărăției, traducere din limba rusă de pr. Boris Răduleanu, București, Editura Sophia, 2012.

10. Sfântul Ioan Gură de Aur, Tratatul despre preoție, în vol. „Despre preoție", traducere, introducere și note de Pr. Dumitru Fecioru, București, Editura Sophia, 2004.

11. Sfântul Ioan Gură de Aur, Din ospățul Stăpânului, introducere, traducere, note și comentarii de Irineu Slătineanul, București, Editura Adonai, 1995.

12. Idem, Omilii la Facere, vol. I, București, Editura Institului Biblic şi de Misiune al Bisericii Ortodoxe Române, 2003.

13. Idem, Tâlcuiri la epistola întâi către Corinteni, Ediţie revizuită de Constantin Făgețan, București, Editura Sophia, 2005.

14. Timiadis Emilianos, Preot, parohie, inoire, București, Editura Sophia, 2001.

15. Zizioulas Ioannis, Euharistie, Episcop, Biserică. Unitatea Bisericii în dumnezeiasca Euharistie și episcop în primele trei secole creștine, București, Editura Basilica, 2009.

Surse Web: 1. www.ziarullumina.ro; 2. www.ires.com. 